\title{
Short communication: Relationship between metabolic status and the milk concentrations of haptoglobin and lactoferrin in dairy cows during early lactation
}

\author{
S. Hiss, C. Weinkauf, S. Hachenberg, ${ }^{1}$ and H. Sauerwein ${ }^{2}$ \\ Institute of Animal Science, Physiology and Hygiene Unit, University of Bonn, 53115 Bonn, Germany
}

\begin{abstract}
To investigate the relationship between metabolic status and the acute phase proteins haptoglobin ( $\mathrm{Hp})$ and lactoferrin (Lf) in milk, the concentrations of $\beta$-hydroxybutyrate (BHBA), nonesterified fatty acids (NEFA) and Hp were determined in blood samples collected weekly from 4 wk prepartum until 12 wk postpartum. Haptoglobin and Lf were determined in weekly milk samples. The cows $(\mathrm{n}=49)$ were retrospectively classified according to NEFA and BHBA concentrations using different time intervals and threshold values for NEFA and BHBA, respectively. For BHBA, 4 threshold concentrations, $(0.8,1.0,1.2$, and $1.6 \mathrm{mM})$ were evaluated either at the first week before calving, at wk 1 or 2 postpartum, or when considering the means of wk 2 and 3 postpartum. For NEFA, the tested thresholds were 0.5 and $0.6 \mathrm{~m} M$ at wk 1 prepartum, wk 1 or 2 postpartum, or the means of wk 1 and 2 postpartum. All variables showed changes during the interval of observation. Comparing the time course of the acute phase proteins in the subgroups classified according to BHBA or NEFA, consistently greater concentrations of $\mathrm{Hp}$ in serum and milk and of Lf in milk were observed in those animals with BHBA concentrations above 1.6 $\mathrm{m} M$ during the last week before calving $(\mathrm{n}=3 / 47)$ than in those with BHBA concentrations below this threshold. For NEFA, analogous differences for $\mathrm{Hp}$ in both serum and milk $(0.52 \pm 0.07$ and $18.1 \pm 4.6$ for NEFA $>0.6 \mathrm{~m} M$ vs. $0.36 \pm 0.04 \mathrm{mg} / \mathrm{mL}$ and $8.46 \pm$ $1.63 \mu \mathrm{g} / \mathrm{mL}$ for NEFA $<0.6 \mathrm{mM}$, respectively) and for Lf in milk $(130 \pm 8.5$ vs. $89.2 \pm 7.1 \mu \mathrm{g} / \mathrm{mL}$, respectively) were detected when a threshold of $0.6 \mathrm{mM}$ at wk 2 postpartum was used. Our results indicated that cows having BHBA and NEFA serum concentrations above these thresholds at defined times could be identified.
\end{abstract}

Received August 13, 2008.

Accepted May 27, 2009.

${ }^{1}$ Present address: Federal Research Institute of Animal Health (FLI), Institute of Animal Nutrition, 38116 Braunschweig, Germany.

${ }^{2}$ Corresponding author: sauerwein@uni-bonn.de
Key words: mammary, lactation, haptoglobin, lactoferrin

The periparturient period in dairy cows is characterized by extensive neuroendocrine and metabolic changes (Goff and Horst, 1997). In addition, the incidence of disease is increased (Mallard et al., 1998) because of immunosuppression, which can be ascribed to endocrine and metabolic changes. The onset of lactation is associated with a temporary state of negative energy balance during which the circulating concentrations of NEFA and ketone bodies increase (Doepel et al., 2002). Both NEFA and BHBA exhibit negative effects on leukocytes (Hoeben et al., 2000; Lacetera et al., $2004,2005)$. The reduced activity of leukocytes in the presence of high ketone concentrations facilitates the invasion of pathogens and mastitis (Suriyasathaporn et al., 2000). Intramammary infections are accompanied by increased levels of acute phase proteins (APP); for example, serum amyloid A, and lactoferrin (Lf) and haptoglobin $(\mathbf{H p})$ in milk, as well as by increased expression of their mRNA in epithelial cells (Molenaar et al., 1996; Eckersall et al., 2006; Thielen et al., 2007). Nonetheless, there is little information concerning the relationship between APP in milk and metabolic stress under field conditions. We hypothesized that periparturient metabolic stress as indicated by increased circulating concentrations of NEFA and BHBA results in increased concentrations of APP both in circulation and in milk and that this increase in APP is maintained well beyond the time of the metabolic stress. By applying defined thresholds at the late prepartum and early postpartum phase, our objective was to test whether milk concentrations of $\mathrm{Hp}$ and Lf and serum concentrations of $\mathrm{Hp}$ during the first 12 wk of lactation might be increased in cows that are classified as metabolically stressed.

Forty-nine Holstein Friesian cows (lactation number $3.3 \pm 0.3)$ were studied. They were housed in freestall barns at the agricultural research center of the North Rhine Westphalian Chamber of Agriculture (Riswick, Kleve, Germany). Cows were fed a TMR based on grass 
and corn silage for ad libitum intake (6.6 MJ of $\mathrm{NE}_{\mathrm{L}} /$ $\mathrm{kg}$ of DM). Amounts offered and refused were recorded daily to maintain approximately $10 \%$ (5 to $15 \%$ ) orts. In addition to the TMR, lactating animals received increasing amounts of concentrate according to their individual milk yield, but the concentrate was limited to $7 \mathrm{~kg} / \mathrm{d}$ per cow. During the dry period, cows were fed a ration satisfying the demand for maintenance and the additional energetic needs of the conceptus and the mammary gland (i.e., $13 \mathrm{MJ}$ of $\mathrm{NE}_{\mathrm{L}} / \mathrm{d}$ from wk -6 to wk -4 prepartum and $18 \mathrm{MJ}$ of $\mathrm{NE}_{\mathrm{L}} / \mathrm{d}$ from wk -3 prepartum until calving, respectively) according to the recommendations of the German Society of Nutrition Physiology (GfE, 2001). During the first 12 wk of lactation, daily milk yield was $37.1 \pm 0.96 \mathrm{~kg}$ of ECM.

Blood samples were collected weekly via jugular venipuncture from wk -4 to wk 12 postpartum, approximately $4 \mathrm{~h}$ after the morning feeding. Serum was harvested after centrifugation $(20 \mathrm{~min}$ at $3,000 \times g$, room temperature) and stored at $-20^{\circ} \mathrm{C}$. Milk samples were collected during the evening milking from each gland after discarding the first milk (approximately 20 $\mathrm{mL}$ per quarter). After centrifugation (20 min at 3,000 $\times g$ and $4^{\circ} \mathrm{C}$ ), the fat layer was discarded and the skim milk samples obtained were stored at $-20^{\circ} \mathrm{C}$.

The concentrations of $\mathrm{Hp}$ and Lf were measured by using double-antibody enzyme immunoassays as described by Hiss et al. (2004) and Schmitz et al. (2004), respectively. The Hp immunoassay was used with slight modifications; that is, instead of using Hp purified from bovine serum, a standard serum was applied for coating plates and as a calibration curve. The serum used had been calibrated against a standard obtained from a European Union Concerted Action on the standardization of animal acute phase proteins (QLK5-CT-1999-0153; Skinner, 2001).

The serum concentrations of NEFA were measured using an enzymatic test kit (kit no. 1383175; Roche, Mannheim, Germany) in which the volumes were reduced for use on microtiter plates. The BHBA was measured at a commercial laboratory (Laboratory for Veterinary Medicine, Cologne, Germany) using a kit (RB 1008) from Randox (Antrim, UK).

All statistical analyses were performed with the SPSS program version 12.0 (SPSS GmbH Software, Munich, Germany). The BHBA and NEFA concentrations recorded weekly were used to divide the animals into groups that were either above or below different threshold values from different sampling times. Four BHBA threshold concentrations, $(0.8,1.0,1.2$, and 1.6 $\mathrm{m} M$ ) were evaluated at the last week before calving or at wk 1 or 2 after calving, or when considering the means of wk 2 and 3 postpartum. For NEFA, the tested thresholds were 0.5 and $0.6 \mathrm{~m} M$ at wk 1 prepartum, wk 1 or wk 2 postpartum, or the means of wk 1 and 2 postpartum. For the groups, the concentrations of the APP during the first 12 wk of lactation as dependent variable were compared among each of the groups that were below or above the thresholds in a general linear model. The respective classification (concentration of NEFA or BHBA at a given time below or above the respective threshold) was tested as a fixed effect. In addition, parturition was considered via nested periods (before and after parturition) within sampling weeks. Sampling week was considered as a repeated effect. Three covariance structures (first-order ante dependence, first-order auto regressive, and heterogeneous first-order auto regressive) were initially tested, and the one with the lowest value of the Akaike's information criterion was then applied. Variation in the data was expressed as SEM. Significance was declared at $P \leq$ 0.05 .

The concentration of serum Hp was affected by calving $(P<0.001)$ with low levels 4 wk prepartum $(0.19$ $\pm 0.03 \mathrm{mg} / \mathrm{mL}$ ) and elevated levels 1 wk postpartum $(1.6 \pm 0.27 \mathrm{mg} / \mathrm{mL})$. Basal levels were reached $3 \mathrm{wk}$ postpartum $(0.34 \pm 0.09 \mathrm{mg} / \mathrm{mL})$. The Hp concentrations in composite milk samples were highest in the first week after parturition $(54 \pm 17 \mu \mathrm{g} / \mathrm{mL})$ and decreased to a basal level of $3.9 \pm 0.8 \mu \mathrm{g} / \mathrm{mL}$ at wk 6 postpartum. Haptoglobin concentrations in milk and blood were correlated $(\mathrm{r}=0.6 ; P<0.001)$. For Lf in milk, the concentrations ranged from $180 \pm 24 \mu \mathrm{g} / \mathrm{mL}$ in the first week postpartum to $76 \pm 8 \mu \mathrm{g} / \mathrm{mL}$ in wk 4 postpartum.

The comparisons of the groups defined according to their NEFA and BHBA concentrations at different times with regard to the time courses of the Hp concentrations in serum and milk, as well as the Lf milk values, yielded several differences as summarized in Table 1. When using BHBA concentrations for classifying the cows, fewer significant differences were observed among the respective groups for $\mathrm{Hp}$ and $\mathrm{Lf}$ in milk than with NEFA. Greater $(P<0.05)$ concentrations of Hp in serum and milk and of Lf in milk were observed throughout the experiment in those animals with BHBA concentrations above $1.6 \mathrm{~m} M$ during the last week before calving. The number of animals in this comparison was unbalanced with only 3 cows classified as being above $1.6 \mathrm{~m} M$ BHBA. For NEFA, differences for Hp in both milk and serum and for Lf in milk were detected if a threshold of $0.6 \mathrm{mM}$ at wk 2 postpartum was used. When a threshold of $0.5 \mathrm{~m} M$ NEFA at the last week before calving was used, the significant differences in the timely changes of the APP were limited to milk Hp and Lf. Comparing the time course of the APP in the subgroups classified according to NEFA, consistently greater concentrations of $\mathrm{Hp}$ in serum and milk and of 
Table 1. Classification criteria for BHBA and NEFA and results of comparing the acute phase protein time courses in cows ${ }^{1}$

\begin{tabular}{|c|c|c|c|c|c|c|c|c|}
\hline \multirow{2}{*}{$\begin{array}{l}\text { Time of } \\
\text { classification }^{2}\end{array}$} & \multirow[b]{2}{*}{$\mathrm{n}<\mathrm{BHBA}>\mathrm{n}^{3}$} & \multirow[b]{2}{*}{$\mathrm{n}<\mathrm{NEFA}>\mathrm{n}^{4}$} & \multicolumn{6}{|c|}{ Variable affected by BHBA or NEFA classification ( $P$-value $)$} \\
\hline & & & BHBA & NEFA & BHBA & NEFA & BHBA & NEFA \\
\hline-1 & $36<0.8>13$ & $42<0.5>7$ & NS & NS & NS & $<0.001$ & NS & 0.007 \\
\hline 1 & $28<0.8>21$ & $31<0.5>18$ & NS & NS & NS & NS & NS & 0.067 \\
\hline 2 & $24<0.8>25$ & $33<0.5>16$ & NS & 0.044 & NS & NS & NS & 0.033 \\
\hline-1 & $43<1.2>6$ & - & NS & - & 0.026 & - & NS & - \\
\hline 1 & $40<1.2>9$ & - & NS & - & NS & - & NS & - \\
\hline 2 & $36<1.2>13$ & - & NS & - & NS & - & NS & - \\
\hline-1 & $46<1.6>3$ & - & 0.033 & - & $<0.001$ & - & 0.001 & - \\
\hline 1 & $42<1.6>7$ & - & $\mathrm{NS}$ & - & NS & - & NS & - \\
\hline 2 & $42<1.6>7$ & - & NS & - & NS & - & NS & - \\
\hline $1+2^{5}$ & - & $35<0.6>14$ & NS & NS & NS & NS & NS & 0.024 \\
\hline
\end{tabular}

Lf in milk were observed in those animals with NEFA concentrations $>0.6 \mathrm{~m} M$ than in those with $<0.6 \mathrm{mM}$ concentrations (Figure 1). For NEFA differences for Hp in both serum and milk $(0.52 \pm 0.07$ and $18.1 \pm 4.6$ for NEFA $>0.6 \mathrm{~m} M$ vs. $0.36 \pm 0.04$ and $8.46 \pm 1.63$ $\mathrm{mg} / \mathrm{mL}$ for NEFA $<0.6 \mathrm{~m} M$, respectively) and for Lf in milk (130 \pm 8.5 vs. $89.2 \pm 7.1$, respectively) were detected if a threshold of $0.6 \mathrm{~m} M$ at wk 2 postpartum was used. Figure 1 shows the changes of the milk Hp and Lf concentrations for 2 of the NEFA classification modes that were found to yield significant differences (Table 1).

The different thresholds used for BHBA and NEFA were largely based on the literature. For BHBA, various threshold concentrations were suggested with respect to subclinical ketosis ( $>1 \mathrm{~m} M$ : Whitaker et al., 1999; $>1.2 \mathrm{~m} M$ : Clark et al., 2005; >1.4 mM: Geishauser et al., 2000). Suriyasathaporn et al. (1999) classified cows based on BHBA serum concentrations into low-BHBA $(<0.8 \mathrm{mM})$, medium-BHBA $(>0.8$ and $<1.6 \mathrm{mM})$, and high-BHBA cows $(>1.6 \mathrm{mM})$. They observed lower chemotaxis differentials in white blood cells derived from high-BHBA cows than from low-BHBA cows. With regard to mastitis, Janosi et al. (2003) reported that BHBA concentrations $>1 \mathrm{~m} M$ in the first $3 \mathrm{~d}$ after parturition were regarded as predisposition to develop mastitis in the next 4 wk. For NEFA, the threshold con- centrations reported were limited to prepartum values: concentrations $>0.5 \mathrm{mM}$ during the last 4 wk before calving were indicative of negative energy balance, and cows exceeding this threshold had greater likelihood for developing postpartum disorders (LeBlanc et al., 2005). No defined threshold for plasma NEFA exists for postpartum cows (Nafikov et al., 2006) to describe clinical endpoints, but using $0.5 \mathrm{~m} M$ NEFA from wk 1 postpartum was identified as effective in identifying (subtle) metabolic stress (Hachenberg et al., 2007).

Increased serum Hp levels around parturition support a previous report (Uchida et al., 1993). There is little information concerning the link between serum Hp and metabolic stress. Yoshino et al. (1992) reported the appearance of $\mathrm{Hp}$ in cows with fatty liver, and Crawford et al. (2005) speculated that the increase of Hp around parturition might be partly caused by negative energy balance. Waldron et al. (2006) addressed the causal-mechanistic relationship between mastitis and metabolic disorder: they demonstrated that an experimentally induced mastitis did not result in energyrelated metabolic disorders. The relationship between milk Hp concentrations and NEFA was confirmed when grouping the animals according to their milk $\mathrm{Hp}$ values (Table 1) and following up the NEFA time course; that is, cows with elevated Hp milk concentrations had higher NEFA values (data not shown). Nonetheless, 


\section{Grouping according to NEFA in wk 1 a.p. $(<$ or $>0.5 \mathrm{mM})$}

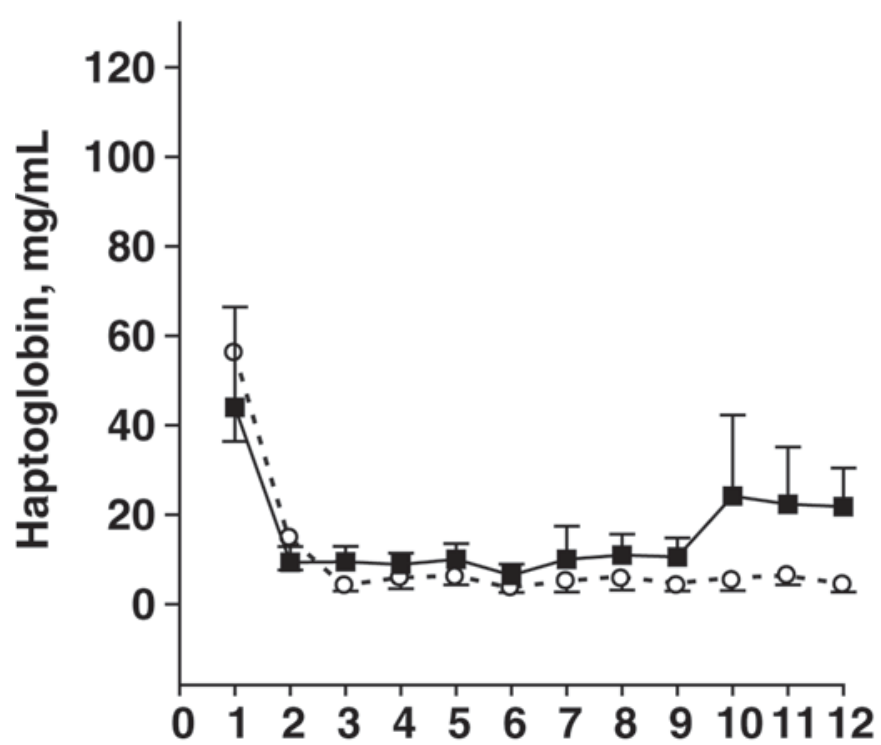

\section{Grouping according to NEFA}

in wk 2 p.p. $(<$ or $>0.6 \mathrm{mM})$

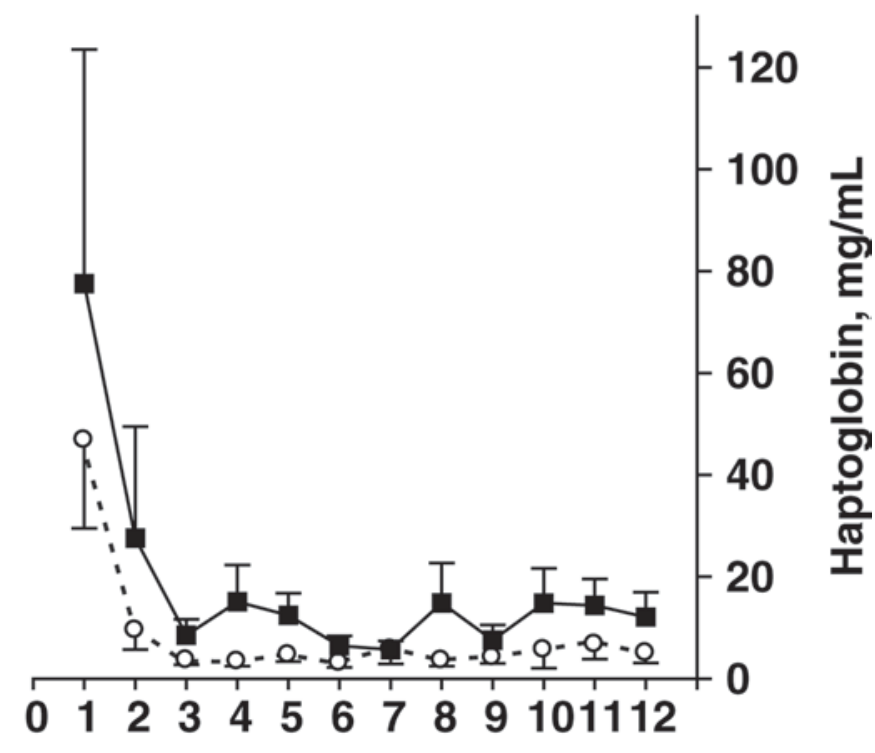

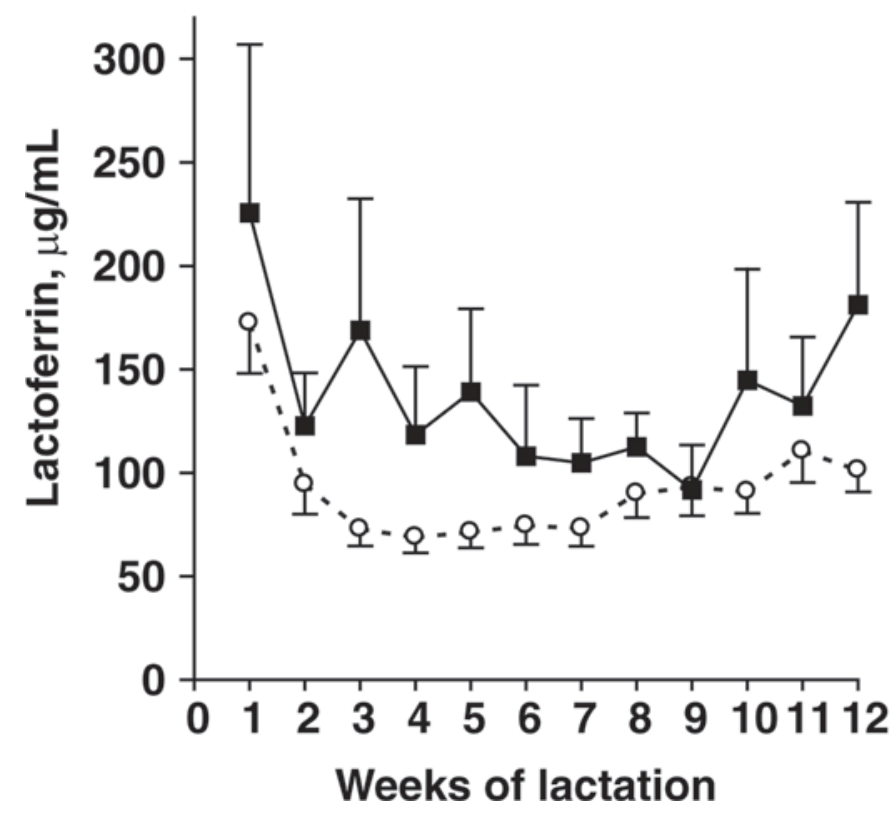

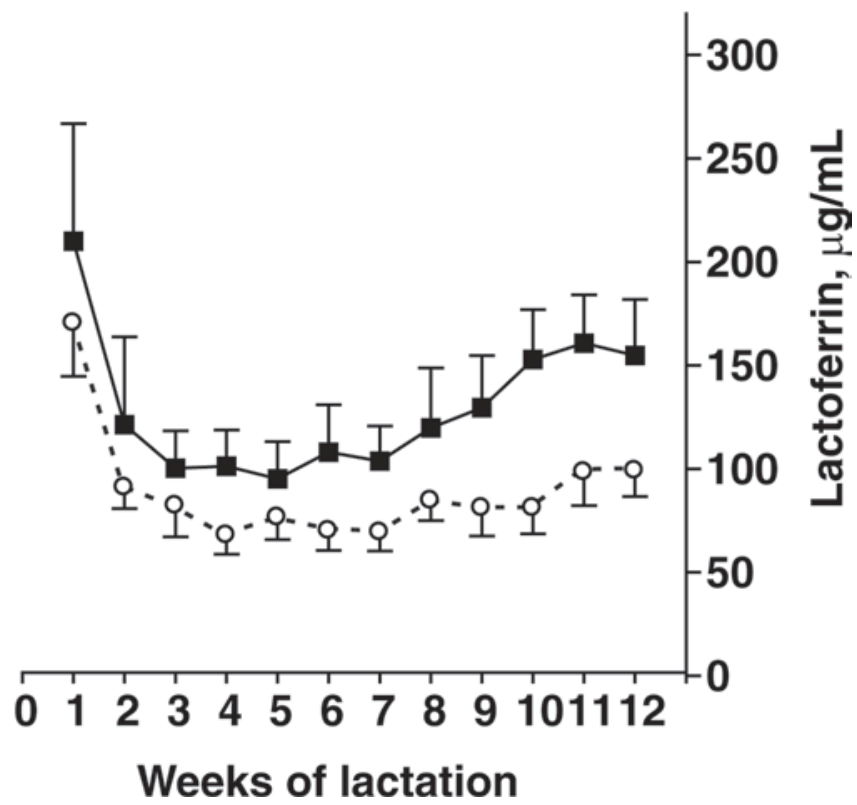

Figure 1. Examples of changes in the concentrations of haptoglobin and lactoferrin in milk from cows classified by their NEFA concentrations at 1 wk prepartum (a.p.) and 2 wk postpartum (p.p.). In total, 49 cows were classified as being either below (---O---) or above (-- - $)$ a threshold concentration of NEFA in blood. Cows were grouped according to their NEFA blood concentrations a.p. using a threshold of 0.5 m $M$ (panels on the left-hand side) or p.p. with a $0.6 \mathrm{~m} M$ threshold (panels on the right-hand side). Haptoglobin data are shown in the upper panels, and lactoferrin data are presented in the lower panels. Means \pm SEM are given; the $P$-values for the statistical comparisons are in Table 1 .

elevated Hp concentrations in milk may at least in part contribute to circulating Hp (Hiss et al., 2004; Thielen et al., 2007).

For milk Hp and Lf, NEFA classifications yielded more differences than did BHBA grouping (Table 1). Moreover, the BHBA threshold concentrations at which differences in $\mathrm{Hp}$ and Lf were detectable were relatively high (>1.6 $\mathrm{mM}$ at $-1 \mathrm{wk})$, and their occurrence was untypically early and limited to 3 cows. In contrast, the results from the NEFA classification with larger animal numbers might indicate the extent of fat mobilization occurring around calving affecting the mammary de- 
fense mechanisms well beyond the time of increased NEFA exposure.

\section{ACKNOWLEDGMENTS}

This study was supported by the North RhineWestphalian Ministry of Environment, Conservation, Agriculture and Consumers Protection (MUNLV) within the Inter-Departmental Center of Sustainable Agriculture (USL). C. Weinkauf was supported by the Deutsche Bundesstiftung Umwelt (DBU). We thank Birgit Mielenz and Karin Strack for their excellent technical assistance.

\section{REFERENCES}

Clark, C. E. F., W. J. Fulkerson, K. S. Nandra, I. Barchia, and K. L. Macmillan. 2005. The use of indicators to assess the degree of mobilisation of body reserves in dairy cows in early lactation on a pasture-based diet. Livest. Prod. Sci. 94:199-201.

Crawford, R. G., K. E. Leslie, R. Bagg, C. P. Dick, and T. F. Duffield. 2005. The impact of controlled release capsules of monensin on postcalving haptoglobin concentrations in dairy cattle. Can. J. Vet. Res. 69:208-214.

Doepel, L., H. Lapierre, and J. J. Kennelly. 2002. Peripartum performance and metabolism of dairy cows in response to prepartum energy and protein intake. J. Dairy Sci. 85:2315-2334.

Eckersall, P. D., F. J. Young, A. M. Nolan, C. H. Knight, C. McComb, M. M. Waterston, C. J. Hogarth, E. M. Scott, and J. L. Fitzpatrick. 2006. Acute phase proteins in bovine milk in an experimental model of Staphylococcus aureus subclinical mastitis. J. Dairy Sci. 89:1488-1501.

Geishauser, T., K. Leslie, J. Tenhag, and A. Bashiri. 2000. Evaluation of eight cow-side ketone tests in milk for detection of subclinical ketosis in dairy cows. J. Dairy Sci. 83:296-299.

GfE (Gesellschaft für Ernährungsphysiologie). 2001. Ausschuss für Bedarfsnormen der Gesellschaft für Ernährungsphysiologie. Nr. 8. Empfehlungen zur Energie-und Nährstoffversorgung der Milchkühe und Aufzuchtrinder. DLG-Verlag, Frankfurt am Main, Germany.

Goff, J. P., and R. L. Horst. 1997. Physiological changes at parturition and their relationship to metabolic disorders. J. Dairy Sci. 80:1260-1268.

Hachenberg, S., C. Weinkauf, S. Hiss, and H. Sauerwein. 2007. Evaluation of classification modes potentially suitable to identify metabolic stress in healthy dairy cows during the peripartal period. J. Anim. Sci. 85:1923-1932.

Hiss, S., M. Mielenz, R. M. Bruckmaier, and H. Sauerwein. 2004. Haptoglobin concentrations in blood and milk after endotoxin challenge and quantification of mammary Hp mRNA expression. J. Dairy Sci. 87:3778-3784.

Hoeben, D., E. Monfardini, G. Opsomer, C. Burvenich, H. Dosogne, A. DeKruif, and J. F. Beckers. 2000. Chemiluminescence of bovine polymorphonuclear leucocytes during the periparturient period and relation with metabolic markers and bovine pregnancy-associated glycoprotein. J. Dairy Res. 67:249-259.

Janosi, S., M. Kulcsar, P. Korodi, L. Katai, J. Reiczigel, S. J. Dieleman, J. A. Nicoloc, G. Salyi, P. Ribiczey-Szabo, and G. Huszenica. 2003.
Energy imbalance related predisposition to mastitis in group-fed high producing postpartum dairy cows. Acta Vet. Hung. 51:409424

Lacetera, N., D. Scalia, U. Bernabucci, B. Ronchi, D. Piazzi, and A. Nardone. 2005. Lymphocyte functions in overconditioned cows around parturition. J. Dairy Sci. 88:2010-2016.

Lacetera, N., D. Scalia, O. Franci, U. Bernabucci, B. Ronchi, and A. Nardone. 2004. Effects of nonesterified fatty acids on lymphocyte function in dairy heifers. J. Dairy Sci. 87:1012-1014.

LeBlanc, S. J., K. E. Leslie, and T. F. Duffield. 2005. Metabolic predictors of displaced abomasum in dairy cattle. J. Dairy Sci. $88: 159-170$.

Mallard, B. A., J. C. Dekkers, M. J. Ireland, K. E. Leslie, S. Sharif, C. Lacey, L. W. Vankampen, and B. N. Wilkie. 1998. Alteration in immune responsiveness during the peripartum period and its ramification on dairy cow and calf health. J. Dairy Sci. 81:585595

Molenaar, A. J., Y. M. Kuys, S. R. Davis, R. J. Wilkins, P. E. Mead, and J. W. Tweedie. 1996. Elevation of lactoferrin gene expression in developing, ductal, resting, and regressing parenchymal epithelium of the ruminant mammary gland. J. Dairy Sci. 79:1198-1208.

Nafikov, R. A., B. N. Ametaj, G. Bobe, K. J. Koehler, J. W. Young, and D. C. Beitz. 2006. Prevention of fatty liver in transition dairy cows by subcutaneous injections of glucagon. J. Dairy Sci. 89:1533-1545.

Schmitz, S., M. W. Pfaffl, M. Miller, J. Buchberger, T. Meyer, H. Sauerwein, and R. M. Bruckmaier. 2004. mRNA expression of immune factors and milk proteins in mammary tissue and milk cells and their concentration in milk during subclinical mastitis. Milk Sci. Int. 59:351-355.

Skinner, J. G. 2001. International standardization of acute phase proteins. Vet. Clin. Pathol. 30:2-7.

Suriyasathaporn, W., A. J. Daemen, E. N. Noordhuizen-Stassen, S. J. Dieleman, M. Nielen, and Y. H. Schukken. 1999. Betahydroxybutyrate levels in peripheral blood and ketone bodies supplemented in culture media affect the in vitro chemotaxis of bovine leukocytes. Vet. Immunol. Immunopathol. 68:177-186.

Suriyasathaporn, W., C. Heuer, E. N. Noordhuizen-Stassen, and Y. H. Schukken. 2000. Hyperketonemia and the impairment of udder defense: A review. Vet. Res. 31:397-412.

Thielen, M., M. Mielenz, S. Hiss, H. Zerbe, W. Petzl, H.-J. Schuberth, H.-M. Seyfert, and H. Sauerwein. 2007. Cellular localization of haptoglobin mRNA in the experimentally infected bovine mammary gland. J. Dairy Sci. 90:1215-1219.

Uchida, E., N. Katoh, and K. Takahashi. 1993. Appearance of haptoglobin in serum from cows at parturition. J. Vet. Med. Sci. 55:893-894.

Waldron, M. R., A. E. Kulick, A. W. Bell, and T. R. Overton. 2006. Acute experimental mastitis is not causal toward the development of energy-related metabolic disorders in early postpartum dairy cows. J. Dairy Sci. 89:596-610.

Whitaker, D. A., W. J. Goodger, M. Garcia, B. M. Perera, and F. Wittwer. 1999. Use of metabolic profiles in dairy cattle in tropical and subtropical countries on smallholder dairy farms. Prev. Vet. Med. 38:119-131.

Yoshino, K., N. Katoh, K. Takahashi, and A. Yuasa. 1992. Purification of a protein from serum of cattle with hepatic lipidosis, and identification of the protein as haptoglobin. Am. J. Vet. Res. 53:951-956. 